Témoigner Témoigner. Entre histoire et mémoire

Getuigen Revue pluridisciplinaire de la Fondation Auschwitz

$123 \mid 2016$

Traduire le témoignage

\title{
Nadia Butt. Transcultural memory and globalised modernity in contemporary indo-english novels
}

Berlin and Boston: de Gruyter, 2015

\section{Sayma Khan}

\section{(2) OpenEdition}

\section{Journals}

Electronic version

URL: https://journals.openedition.org/temoigner/5564

DOI: $10.4000 /$ temoigner.5564

ISSN: 2506-6390

Publisher:

Éditions du Centre d'études et de documentation Mémoire d'Auschwitz, Éditions Kimé

Printed version

Date of publication: 1 October 2016

Number of pages: 199-201

ISBN: 987 2-9600926-4-6

ISSN: 2031-4183

\section{Electronic reference}

Sayma Khan, "Nadia Butt. Transcultural memory and globalised modernity in contemporary indo-english novels", Témoigner. Entre histoire et mémoire [Online], 123 | 2016, Online since 02 November 2021, connection on 04 November 2021. URL: http://journals.openedition.org/temoigner/5564 ; DOI: https:// doi.org/10.4000/temoigner.5564

This text was automatically generated on 4 November 2021

Tous droits réservés 


\section{Nadia Butt. Transcultural memory and globalised modernity in contemporary indo-english novels}

Berlin and Boston: de Gruyter, 2015

\section{Sayma Khan}

\section{REFERENCES}

Nadia Butt. Transcultural memory and globalised modernity in contemporary indo-english novels. Berlin and Boston: de Gruyter, 2015, 213 p.

1 The act of remembering - voluntary or involuntary, within the private or political realm - makes not only the past effective in the present, it concurrently opens up possibilities to negotiate between multiple temporalities that otherwise seem too far apart or unbridgeable. Despite being an intrinsic human practice and a universal phenomenon, the entrance of memory into mainstream political, public and academic discourse remains indebted to the Holocaust and its aftermath. Mnemonic practices related to the remembrance of the Holocaust brought a renewed interest in the field of memory studies towards the second half of the twentieth century and in due time cemented its significance in academia and the political as well as the social domain. Once interest in memory (studies) was awakened, theorists, historians and scholars were led to engage with it in different contexts. However, memory studies' initial propinquity was markedly with nation-states, wherein scholars tried to carve out specific national memories - the most notable example being Nora's Lieux de mémoire (1984-1992), in which he delineates a French national memory based on famous historical places, objects, and personalities. The practice of placing memory within national borders soon came under scrutiny as a rather narrow approach. Cultural memory studies has paved the way for "trans"-cultural memory studies, which critiques and questions claims of monoculturalism within nation-states and stresses the 
need to incorporate diverse and multiple memory cultures outside Europe into its research spectrum.

Nadia Butt's recent book Transcultural Memory and Globalised Modernity in Contemporary Indo-English Novels takes a significant and crucial step in this direction. By emphasizing the social practice of trans-cultural memory, it reveals "the diversity of contemporary cultures and life-forms" and "the significance of 'connective histories' in the realm of memory fiction as an effective media of memory" (23). The concept of transcultural memory, according to Butt, "alerts us to the need for a form of comparative thinking that, like memory itself, is not afraid to traverse fixed borders of ethnicity and nationality" (20). The book develops the concept of transcultural memory with reference to the recent phenomena of globalized modernity and notably laces the discourse of transcultural memory with that of South Asian fiction. Precisely because South Asian novels of memory outlay "the paradoxes of memory, which is as much reliable as unreliable, and as much real as imagined, as we experience within individual or group memories" (55), they serve rather well to "redefine both 'the art of memory' and 'memory cultures' in the realm of literature" (33).

Whereas the first part of Butt's book offers original and efficacious theoretical underpinnings of transcultural memory with regard to contemporary novels in English from the subcontinent, the second part aptly applies theory to novels from the $1980 \mathrm{~s}$ and 1990s, and the final part sheds light on novels from 2000 onwards. A brief look at the ways in which Butt draws upon existing theorizations of (trans)cultural memory in order to redefine them with the South Asian context in mind - and which later inform her close-readings of the chosen novels - serves here to show how the volume fills a lacuna in the field of transcultural memory. Transcultural memory, according to Butt, is first and foremost defined as shared memory, "as a source analyzing the overlapping cultural connections of the carriers as well as inheritors of memory in heterogeneous cultural setups" (17). It also encompasses aspects of dialogic memory "in which cultural connections beyond borders are considered to be an unavoidable reality" (17). Furthermore, it functions as counter memory, "since it not only resurrects silenced as well as forgotten histories, but also challenges the more dominant 'national', statesponsored histories" (18). Finally, transcultural memory works multi-directionally and "highlight $[\mathrm{s}]$ the jagged borders of memory and identity" (18), besides offering a "hermeneutical circle of organic carriers (first generation) and artificial inheritors (second generation) of memory" (19).

The practical part of the book then focuses on "memory as a narrative and thematic device in fiction" and examines "how [post-partition Indo-English] novels interrogate the idea and practice of memory as an individual and collective experience" (5). Articulations and expressions of transcultural memories in these novels help to make sense of "divided" histories as well as to reconcile individuals and societies with historical predicaments. Experiences of partition, exile and expatriation due to globalization processes remain the overarching themes of memory novels discussed in the book. The chosen novelists, Amitav Ghosh, Bapsi Sidhwa, Salman Rushdie, Zulfikar Ghose, Ruth Prawer Jhabvala, Kamila Shamsie, to name but a few, belong to different ethnic, religious and social backgrounds; hence, revisiting the past for each of these writers is both a political and a private endeavor. Yet, Butt heuristically distinguishes between "novels of political memories: partition and reconciliation" on the one hand and "novels of private memories" on the other, to reveal how experiences of national 
conflicts, expatriation, diaspora and displacement affect individuals and societies, and how these experiences are dealt with through fiction.

of the various close-readings, I will briefly focus on the chapter "Phantoms of generational memory: A transcultural portrait of family histories in Ruth Prawer Jhabvala's Shards of Memory (1995)", since in comparison to the other chosen novels, it remains the least researched by literary scholars. Butt offers an in-depth and critical analysis of the novel. At the heart of the narrative is the main protagonist Henry's quest to comprehend his family's association and proclivities with a guru, who exercises a mystic power over the family members. The character of the guru is surrounded by mystery: the narrative withholds his "real" identity, and the reader never knows whether he was a charlatan or a holy man. The family's association with the guru commenced with Henry's great-grandmother, Elsa, who met the guru in the interim period in India after she married an Indian poet, before eventually shifting to England with her lesbian lover Cynthia. Elsa's daughter and Henry's grandmother, Baby, functions as an intermediary and narrates the family past to Henry, who currently resides in New York. The narrative of Shards of Memory is significantly bound together by generational and transcultural mnemonic practices. Apart from the looming presence of an absent guru, "the reader witnesses events of global importance such as the First and Second World Wars, the fall of the British Empire, the independence of India, the Communist Revolution in Russia, Nazi Germany and the Holocaust" (133). The members of each generation express the reverberations of these political, social and historical transformations. In her close-reading of the novel, Butt reveals how "strands of generation, family and memory [in the medium of fiction] reflect present-day cultural fusions across diverse geographical and temporal zones on the one hand, and the making of global memories on the other" (133).

Butt's analysis of Shards of Memory is paradigmatic for the larger undertakings of the book. The basic concern and premise of Butt's work is indeed to establish transcultural memory "as a theoretical tool and critical methodology to investigate the overlapping of geographical, 'national' and cultural borders in the Indo-English novel" (182). She attends to this concern by exploring Indo-English novels from 1980s onwards, and effectively traces how mnemonic practices bind the past and the present together. Finally, it needs to be asserted that the strength of the book lies in its going beyond an exclusive Eurocentric perspective on memory cultures. It pertinently shows that the inclusion of other case studies - such as Indo-English fiction - is a necessary step to do justice to the simultaneous, multiple and overlapping cultures in and of our globalized world.

\section{AUTHORS}

\section{SAYMA KHAN}

Goethe University Frankfurt 